Anthropos: Jurnal Antropologi Sosial dan Budaya (Journal of Social and Cultural Anthropology)

7 (1) (2021): 79-87, DOI: 10.24114/antro.v7i1.24572

Anthropos: Jurnal Antropologi Sosial dan Budaya (Journal of Social and Cultural Anthropology)

Available online http://jurnal.unimed.ac.id/2012/index.php/anthropos

\title{
Pengalaman Kekerasan pada Pedagang Kaki Lima di Indonesia
}

\section{The Violence Experience Against Street Vendors in Indonesia}

\author{
Salma Nur Rahama \& Rina Hermawati* \\ Program Studi Antropologi, Fakultas Ilmu Sosial dan Ilmu Politik, Universitas Padjadjaran, \\ Indonesia
}

Diterima: 25 April 2021; Direview: 03 Mei 2021; Disetujui: 25 Mei 2021

\begin{abstract}
Abstrak
Artikel ini bertujuan untuk menggambarkan pengalaman kekerasan pada PKL di Indonesia meliputi penyebab kekerasan, bentuk kekerasan dan respon PKL terhadap kekerasan yang mereka alami. Penelitian dilakukan dengan menggunakan studi pustaka yang bersumber dari artikel, disertasi/tesis/skripsi, buku dan laporan penelitian terkait kasus-kasus kekerasan yang dialami PKL. Berdasarkan hasil penelitian dapat diketahui bahwa penyebab kekerasan PKL berhubungan dengan kelas antara yang memiliki power dan tidak memiliki power. Power yang dimaksud adalah kekuasaan atau kekuatan yang dimiliki seseorang untuk melakukan hal yang dikehendakinya. Bentuk kekerasan yang dialami PKL dapat diidentifikasikan menjadi tiga bentuk berdasarkan teori Galtung diantaranya 1) kekerasan langsung yang dapat dilihat seperti kekerasan fisik, verbal dan seksual, 2) kekerasan struktural yaitu kekerasan yang tidak dilakukan oleh individu tetapi tersembunyi dalam struktur baik struktur yang lebih kecil maupun struktur yang lebih luas, 3) kekerasan kultural yaitu ruang simbolik yang ada dalam sistem kognisi dan dapat menjadi pendorong adanya kekerasan langsung maupun struktural. Respon PKL terhadap kekerasan yang dialaminya terbagi menjadi dua yaitu melakukan resistensi dan tidak melakukan resistensi.

Kata kunci: Pedagang Kaki Lima; Kekerasan; Konflik; Resistensi
\end{abstract}

\begin{abstract}
This study aims is to describe about the violence experience against street vendors in Indonesia including the causes of violence, forms of violence and street vendors' experience responses to the violence. This research uses qualitative methods with collecting data techniques from literature studies such as, notes, books, papers or articles, journals and so on. The research results showed that the causes of street vendor violence are related to the class that have more power and the class that have less power. The power in question is the power or strength that a person has to do what he wants. The forms of violence experienced by street vendors can be identified into three forms based on Galtung's theory, including direct violence that can be seen such as physical, verbal and sexual violence, then the second is structural violence, namely violence that is not perpetrated by individuals but is hidden in a structure both smaller and smaller structures. broader structure, then the third is cultural violence, namely the symbolic space that exists in the cognition system and can be a driving force for both direct and structural violence. PKL responses to the violence they experience are divided into two, namely resisting and not resisting.

Keywords: Street Vendors; Violence; Conflict; Resistance
\end{abstract}

How to Cite: Rahama, S.N., \& Hermawati, R. (2021). Pengalaman Kekerasan pada PKL di Indonesia. Anthropos: Jurnal Antropologi Sosial dan Budaya (Journal of Social and Cultural Anthropology), 7 (1): 79-87.

*Corresponding author:

E-mail: $\underline{\text { r.hermawati@unpad.ac.id }}$
ISSN 2549-166o (Print)

ISSN 2550-1305 (Online) 


\section{PENDAHULUAN}

Artikel ini membahas tentang pengalaman kekerasan pada Pedagang Kaki Lima (PKL) di berbagai kota di Indonesia. Lebih jauh lagi, artikel ini bertujuan untuk mengetahui bagaimana pengalaman kekerasan yang dialami PKL meliputi penyebab kekerasan, bentuk kekerasan dan respon PKL terhadap kekerasan.

PKL merupakan salah satu aktivitas dalam ekonomi sektor informal yang dapat dengan mudah dijumpai di daerah perkotaan. Menurut peraturan Menteri Dalam Negeri Republik Indonesia (Permendagri) No.41 Tahun 2012, PKL adalah pelaku usaha yang melakukan usaha perdagangan dengan menggunakan sarana usaha bergerak maupun tidak bergerak, menggunakan prasarana kota, fasilitas sosial, fasilitas umum, lahan dan bangunan milik pemerintah dan/atau swasta yang sifatnya sementara atau tidak menetap.

Prinsip berjualan PKL yang berada pada ruang publik ini menjadikan PKL rentan mengalami kekerasan. Kekerasan dapat terjadi dalam berbagai bentuk termasuk pelecehan fisik, verbal, dan seksual. Ini juga dapat mencakup deprivasi ekonomi melalui pendapatan rendah dan tidak teratur atau akses terlarang ke sumber daya produktif dan ruang publik yang berharga (WIEGO, 2018). Menurut ILO dalam WIEGO dibandingkan dengan PKL laki-laki, PKL perempuan lebih rentan terhadap kekerasan terutama kekerasan yang berbasis gender karena persinggungan antara gender dan kondisi kerja yang tidak aman. Sektor, tempat kerja, dan gender semuanya berdampak pada jenis kekerasan yang dialami oleh berbagai kelompok PKL.

Di Indonesia sendiri kasus kekerasan yang dialami PKL banyak terjadi terutama pada saat penertiban antara lain kekerasan fisik, pembongkaran secara paksa lapak PKL dan pengambilan secara paksa atribut yang digunakan oleh PKL (Rusyanti, 2014; Parmody, 2018). Namun, kekerasan tersebut baik yang dilakukan oleh aparat seperti oknum TNI, Polri, Satpol PP ataupun non aparat tidak pernah ada yang diproses secara hukum ataupun menjadi tersangka atas tindak pidana penganiayaan, pengeroyokan, bahkan perusakan barang (Sari, 2017).

Kajian tentang kekerasan terhadap PKL yang pernah dilakukan antara lain membahas tentang bentuk-bentuk kekerasan, penyebab kekerasan, pelaku kekerasan dan respon kekerasan (Aisyah, 2012; Ismail \& Umar, 2018; Parmody, 2018). Keempat kajian tersebut menggambarkan penyebab kekerasan lebih banyak disebabkan karena kebijakan penertiban yang dilakukan oleh pemerintah kota yang sering kali direspon PKL dengan perilaku membandel. Perilaku kekerasan dialami PKL bukan hanya berasal dari pemerintah dan petugas keamanan. Konflik antar PKL, konflik PKL dengan pembeli, konflik PKL dengan preman yang mengambil keuntungan juga kerap kali mewarnai kehidupan PKL. Jenis kekerasan yang dialami oleh PKL berupa kekerasan struktural, langsung dan kultural. Respon PKL terhadap kekerasan pun beragam dari mulai diam sampai dengan melawan.

Artikel ini akan melengkapi kajiankajian sebelumnya yang melihat pengalaman kekerasan pada PKL dengan menggunakan konsep kekerasan menurut Galtung yang didalamnya meliputi kekerasan langsung, kekerasan struktural dan kekerasan kultural (Galtung dalam Santoso, 2002). Selain itu, digunakan pula teori resistensi dari Scott untuk menggambarkan respon PKL terhadap kekerasan tersebut. Resistensi digunakan oleh masyarakat yang tertindas sebagai alat untuk membela hak yang ada pada diri mereka. Hal tersebut yang menjadi alasan bagi kaum yang merasa ditindas untuk mempertahankan subsistensi yang sudah ada dengan cara menolak perubahan yang ditetapkan melalui gerakan perlawanan (Scott, 2000). Berdasarkan definisi diatas maka dapat disimpulkan bahwa resistensi 
adalah sebuah bentuk perlawanan yang dilakukan kelompok subordinat untuk memperjuangkan hak-hak mereka. Scott membagi perlawanan tersebut menjadi dua bagian, yaitu perlawanan publik atau terbuka (public transcript) dan perlawanan tersembunyi atau tertutup (hidden transcript) (Scott, 2000).

\section{METODE PENELITIAN}

Penelitian ini menggunakan metode kualitatif dengan teknik studi pustaka atau kepustakaan. Menurut Creswell penelitian kualitatif adalah jenis penelitian yang mengeksplorasi dan memahami makna di sejumlah individu atau sekelompok orang yang berasal dari masalah social (Creswell, 2016). Dalam tulisan Mirzaqon, Sarwono mengemukakan bahwa penelitian kepustakaan adalah studi yang mempelajari berbagai buku referensi serta hasil penelitian sebelumnya yang sejenis yang berguna untuk mendapatkan landasan teori mengenai masalah yang akan diteliti (Mirzaqon \& Purwoko, 2017)

Tahapan pada penelitian dengan studi pustaka adalah menetukan topik penulisan, penetapan rumusan masalah dan pengumpulan data, analisa data, pengkategorian, penulisan hasil dan pembahasan serta kesimpulan. Pengumpulan data dilakukan dengan cara mempelajari jurnal, artikel, buku, laporan penelitian, laman berita yang terkait dengan topik penelitian yaitu kekerasan terhadap PKL.

\section{HASIL DAN PEMBAHASAN}

Galtung dalam tulisan Santoso mendefinisikan kekerasan sebagai sesuatu yang menyebabkan orang terhalang untuk mengaktualisasikan potensi diri secara wajar. Kekerasan adalah setiap kondisi fisik, emosional, verbal, institusional, struktural atau spiritual, juga perilaku, sikap, kebijakan atau kondisi yang melemahkan, mendominasi atau menghancurkan diri kita sendiri dan orang lain (Santoso T. , 2002).
Sedangkan menurut Menurut Audi dalam tulisan Anjari kekerasan adalah serangan atau penyalahgunaan kekuatan secara fisik terhadap seseorang atau binatang; serangan atau penghancuran, perusakan yang sangat keras, kasar, kejam, dan ganas atas milik atau sesuatu yang sangat potensial dapat menjadi milik seseorang (Anjari, 2017)

Berdasarkan kedua definisi diatas kekerasan merupakan suatu kondisi dimana seseorang menyalahgunakan kekuatan yang dimilikinya sehingga mengakibatkan kehancuran, kerusakan, mendominasi dan melemahkan pada fisik, psikis dan kejiwaan objek yang terkena kekerasan baik seseorang, diri sendiri maupun sesuatu yang potensial yang dimiliki oleh seseorang. Galtung memperkenalkan teori segitiga kekerasan yang di dalamnya meliputi kekerasan langsung, kekerasan struktural dan kekerasan kultural. Berdasarkan literatur yang ditemukan kekerasan pada PKL terdiri dari penyebab kekerasan, bentuk kekerasan dan respon PKL terhadap kekerasan.

Kekerasan pada PKL di Indonesia disebabkan oleh kebijakan pemerintah terkait penertiban PKL. Kekerasan yang diakibatkan adanya pelaksanaan kebijakan penertiban disebabkan karena perbedaan visi dan misi antara PKL dan pemerintah kota. Konflik tersebut bersumber dari perbedaan penafsiran dan makna ruang publik diantara keduanya. Para PKL memaknai tempat umum sebagai tempat yang strategis untuk menjalankan usahanya dan berusaha mempertahankan keberadaannya di dalamnya, sedangkan pemerintah memiliki visi menjaga ketertiban dan kenyaman di kota dengan misi mencoba mengendalikan PKL di tempat umum (Hakim, Rosmawati, Zainuddin, Halim, \& Mana, 2015; Hermawati, Abdoellah, Gunawan, \& Riawanti, 2019; Handoyo, 2015).

Dalam berbagai macam artikel disebutkan bahwa keberadaan PKL sering 
mengundang konflik pemanfaatan tata ruang, karena menyebabkan kemacetan lalu-lintas, kesemerawutan kota, dan kekumuhan lingkungan. Oleh karena itu pemerintah kota mengeluarkan kebijakan tentang penertiban dan penggusuran terhadap para PKL dan memindahkan PKL dari jalan, mendaftarkannya, serta memindahkannya ke sebuah tempat berupa gedung untuk mereka berjualan atau biasa disebut relokasi (Hakim, Rosmawati, Zainuddin, Halim, \& Mana, 2015; Handoyo, 2015; Husain, Jers, \& Suraya, 2017; Human Right, 2013).

Pada saat melakukan kebijakan penertiban terhadap PKL sering kali diwarnai dengan aksi kekerasan. Seeperti yang ditemukan di dalam artikel kekerasan PKL di Surabaya, Menur, Semolowaru dan Madiun terjadi gesekan antara PKL dan petugas penertiban kota karena PKL berusaha untuk menyelamatkan lapak berdagang mereka dengan cara tetap berjualan dan menghalangi petugas yang sedang melakukan aksi penertiban, sehingga petugas kerap kali harus melakukan kekerasan (Parmody, 2018; Husain, Jers, \& Suraya, 2017; Prastya, 2018).

Pada saat melakukan relokasi PKL melakukan penolakan karena mereka khawatir akan kehilangan pelanggan yang biasa membeli dagangan mereka jika mereka pindah ke tempat yang baru, para PKL juga khawatir dengan biaya sewa kios di tempat baru yang tentunya berbeda dengan tempat mereka berjualan sebelumnya yang terbebas dari uang sewa, selain itu dengan adanya relokasi akan muncul permasalahan baru seperti sentralisasi tempat berjualan sehingga persaingan berjualan mereka dengan pedagang lainnya akan lebih besar. Karena penolakan yang gencar dilakukan PKL maka petugas keamanan mau tidak mau melakukan kekerasan terhadap mereka (Febrianto \& Imron, 2014; Husain, Jers, \& Suraya, 2017; Prastya, 2018; Human Right, 2013; Parmody, 2018).
Dalam teori konflik, masyarakat dipandang sebagai sistem sosial yang terdiri atas kepentingan-kepentingan yang berbeda-beda dimana ada suatu usaha untuk menaklukkan komponen yang lain guna memenuhi kepentingan lainnya atau memproleh kepentingan sebesar-besarnya (Ritzer \& Goodman, 2004). Dahrendrof mengatakan di dalam tulisan Ritzer dan Goodman bahwa Kekuasaan dan wewenang senantiasa menempatkan individu pada posisi atas dan posisi bawah dalam setiap struktur. Karena wewenang itu adalah sah, maka setiap individu yang tidak tunduk terhadap wewenang yang ada akan terkena sanksi. Dengan demikian, masyarakat disebut sebagai persekutuan yang terkoordinasi secara paksa. Oleh karena itu kekuasaan selalu memisah dengan tegas antara penguasa dan yang dikuasai, maka dalam masyarakat selalu terdapat dua golongan yang saling bertentangan (Ritzer \& Goodman, 2004).

Sejalan dengan teori yang dikemukakan Dahrendorf, konflik antara PKL dengan pemerintah kota merupakan konflik karena adanya perbedaan kepentingan. PKL memiliki kepentingan untuk berjualan dan mendapatkan uang sedangkan pemerintah kota memiliki kepentingan untuk menjaga kotanya untuk tetap aman dan nyaman. Berdasarkan hasil temuan dapat terlihat bahwa posisi PKL berada dalam subordinat sedangkan posisi pemerintah adalah superordinat.

Pemerintah memiliki otoritas tinggi untuk mengatur kota yang diperintahnya. Kegiatan penertiban yang dilakukan pemerintah merupakan salah satu bentuk otoritas mereka dalam hal penataan kota. PKL dianggap sebagai suatu entitas yang mengurangi keindahan kota, oleh sebab itu pemerintah melakukan penertiban dan timbullah konflik.

Bentuk kekerasan yang timbul diantaranya kekerasan fisik, kekerasan verbal dan kekerasan struktural. Bentuk kekerasan pertama yaitu kekerasan fisik. Kekerasan fisik adalah tindakan yang 
dilakukan orang untuk menyakiti tubuh atau merusak kepunyaan orang lain. Kekerasan fisik bukan hanya menyerang fisik dalam artian tubuh korbannya, tetapi juga menyerang harta benda kepunyaan korban tersebut dan mengakibatkan kelenyapan. Berdasarkan artikel yang sudah didapat, kekerasan fisik sendiri merupakan kekerasan yang paling banyak dialami oleh PKL.

Bentuk kekerasan fisik yang banyak terjadi adalah bentrok fisik antara petugas keamanan dan PKL. Seperti yang sudah dijelaskan sebelumnya bahwa PKL dan petugas keamanan kerap kali melakukan bentrokan fisik pada saat kegiatan penertiban. Bentuk kekerasan fisik yang menyerang anggota tubuh para PKL oleh para petugas keamanan adalah pemukulan, pengeroyokan, penahanan beberapa PKL, menendang PKL, menampar PKL, meninju pada bagian dada dan wajah PKL, menarik lengan secara paksa dan sebagainya. (Febrianto \& Imron, 2014; Human Right, 2013; Musoni, 2010; Bhimji, 2010; Xu \& Jiang, 2019; Hanser, 2016; Hermawati, Abdoellah, Gunawan, \& Riawanti, 2019; Abebe, 2017; Prastya, 2018).

Selain kekerasan berupa penyerangan terhadap anggota tubuh saja, ditemukan pula kekerasan terhadap harta benda. Pada saat penertiban, petugas keamanan kerap kali melakukan pembongkaran lapak secara paksa, pengrusakan barang dagangan PKL, pengrusakan sarana berdagang PKL seperti gerobak dan sebagainya, penyitaan barang dagangan PKL dan pembakaran lapak PKL secara besar-besaran. Dalam kasus pengrusakan lapak PKL, petugas keamanan menggunaan alat berat seperti buldozer dan alat berat lainnya sehingga tindakan tersebut sulit untuk dihindari. Hal tersebut terjadi pada PKL di Jakarta dan Surabaya (Parmody, 2018; Adicahya, 2017; Hermawati, Abdoellah, Gunawan, \& Riawanti, 2019; Handoyo, 2015; Sundalangi, 2009; Husain, Jers, \& Suraya, 2017; Febrianto \& Imron, 2014; Adama, 2020).
Bentuk kekerasan selanjutnya adalah kekerasan verbal. Kekerasan verbal adalah kekerasan yang muncul dari ucapan atau kata-kata tanpa menyentuh secara langsung fisik dari si korban. Contoh kekerasan verbal adalah makian, omelan, bentakan, ancaman dan kata-kata lainnya yang bersifat menakuti, mengintimidasi, membesar-besarkan serta menjatuhkan orang lain. Kasus kekerasan verbal dapat dilakukan oleh seseseorang ke seseorang lainnya, seseorang ke sekelompok orang, sekelompok orang ke seseorang dan sekelompok orang ke sekelompok orang lainnya.

Kasus kekerasan verbal yang melibatkan PKL dan petugas kemanan terjadi pada PKL di Salatiga, PKL di Madiun dan PKL di Losari. Kasus kekerasan verbal yang dilakukan petugas keamanan kepada PKL diantaranya menghardik, membentak, mengeluarkan ancaman, berteriak di depan wajah PKL dengan kata yang tidak senonoh, memberikan stigma yang buruk seperti menyebutnya sebagai "orang rendahan", mengejek dan merendahkan PKL menggunakan kata-kata yang kasar dan sebagainya (Hakim, Rosmawati, Zainuddin, Halim, \& Mana, 2015; Prastya, 2018; Ningsih, 2018).

Berdasarkan teori Galtung kekerasan fisik seperti pemukulan, pengeoyokan, penggusuran lapak, pengahancuran barang dagangan dan kekerasan verbal seperti ancaman dan ejekan yang dialami oleh PKL termasuk ke dalam kekerasan langsung karena kekerasan tersebut dapat dilihat secara langsung, nyata dan riil.

Bentuk kekerasan yang terakhir yang ditemukan di berbagai artikel adalah kekerasan struktural. Kekerasan struktural adalah kekerasan yang diakibatkan oleh struktur sosial. Di dalam kehidupan bermasyarakat struktur sosial atau tingkatan sosial akan selalu ada. Dalam kekerasan struktural, kekerasan bukan dilakukan oleh perorangan tetapi sekelompok orang. Biasanya kekerasan terjadi karena struktur masyarakat yang 
lebih tinggi merasa memiliki kekuatan yang lebih dibandingkan masysrakat pada struktur dibawah mereka, sehingga baik sadar dan tidak sadar mereka melakukan tindakan kekerasan.

Kasus kekerasan struktural adalah penyalahgunaan wewenang petugas keamanan yang diperintah oleh pemeritah kota kepada PKL dalam bentuk pemungutan liar. Para PKL diminta untuk membayar sejumlah uang kepada petugas keamanan atau orang yang berkuasa di daerah tersebut dengan dalih jaminan "keamanan". Selain jaminan keamanan pungutan liar juga dilakukan dengan alasan terhindar dari kegiatan penertiban dan penataan yang dilakukan oleh pemerintah kota. Kekerasan jenis ini terjadi pada PKL di beberapa kota di Indonesia. Pada saat itu petugas keamanan kota diminta untuk mengatasi PKL yang membandel, mereka kerap melakukan patroli. Tetapi dalam menjalankan tugasnya petugas keamanan justru meminta sejumlah uang kepada para PKL (Parmody, 2018; Aisyah, 2012).

Berdasarkan penyebab dan bentuk kekerasan yang dialami PKL, PKL mengeluarkan respon terhadap kekerasan yang dialaminya. Respon adalah reaksi yang dikeluarkan oleh seseorang setelah diterimanya rangsangan. Respon biasanya berbentuk tindakan atau perilaku. Bentuk respon yang dikeluarkan tiap individu maupun kelompok berbeda-beda. Respon PKL terhadap kekerasan yang dialaminya terbagi menjadi dua, PKL yang melakukan resistensi dan PKL yang tidak melakukan resistensi. Resistensi sendiri artinya perlawanan. Resistensi dibagi mejadi dua bentuk yaitu resistensi terbuka dan resistensi tertutup.

Scott mendefinisikan perlawanan atau resistensi sebagai segala tindakan yang dilakukan oleh kaum atau kelompok subordinant yang ditujukan untuk mengurangi atau menolak klaim (misalnya harga sewa atau pajak) yang dibuat oleh pihak atau kelompok superdinant terhadap mereka (Scott, 2000). Scott berpandangan bahwa perlawanan dilakukan karena adanya penindasan yang terjadi dalam keseharian masyarakat. Perlawanan digunakan oleh masyarakat yang tertindas sebagai alat untuk membela hak yang ada pada diri mereka. Hal tersebut yang menjadi alasan bagi kaum yang merasa ditindas untuk mempertahankan subsistensi yang sudah ada dengan cara menolak perubahan yang ditetapkan melalui gerakan perlawanan (Scott, 2000).

Berdasarkan definisi diatas maka dapat disimpulkan bahwa resistensi adalah sebuah bentuk perlawanan yang dilakukan kelompok subordinat untuk memperjuangkan hak-hak mereka. Resistensi terbuka adalah resistensi yang dilakukan secara terang-terangan atau dapat dilihat secara langsung. Resistensi secara terbuka lebih cepat sampai kepada orang yang akan dituju. Dalam merespon kekerasan PKL kerap melakukan resistensi terbuka, PKL tersebut diantaranya PKL Madiun dengan melakukan serangan balik kepada petugas keamanan yang bertindak represif, mereka melawan dengan cara mengadu otot, adu fisik, gontok-gontokan dan tak segan-segan membawa senjata tajam guna melawan petugas keamanan pada saat itu (Prastya, 2018).

PKL di Jawa Timur melakukan resistensi terbuka dengan cara membentuk paguyuban PKL yang didalamnya mengatur tentang pengorganisasian PKL termasuk tidak diperlakukan sewenang-wenang oleh siapapun (Aisyah, 2012). Membuat paguyuban PKL merupakan salah satu cara resistensi terbuka yang sangat terorganisir. Didalam paguyuban tersebut PKL dapat berbagi masalah dan menghadapi masalah secara bersama-sama. Dengan adanya paguyuban yang jelas PKL bisa bekerjasama dengan lembaga-lembaga kemasyarakatan seperti LSM atau LKM. Lembaga tersebut menjadi jembatan antara PKL dan pemerintah untuk menyelesaikan masalah PKL salah satunya yaitu penertiban yang berujung pada kekerasan. 
Masih dalam kasus resistensi terbuka tetapi berbeda jenis. Resistensi terbuka yang dilakukan oleh PKL dalam merespon suatu tindak kekerasan adalah melakukan aksi demontrasi. PKL yang melakukan aksi demo misalnya pernah dilakukan oleh PKL di Kota Bandung. Tuntutan dari aksi tersebut ditujukan kepada pemerintah, oleh karena itu mereka melakukan aksi demontrasi di jalan dan di depan gedung pemerintahan sambil membawa kertas besar berisi slogan dan tuntutan yang mereka tuntut. Aksi demontrasi yang dilakukan oleh para PKL memiliki berbagai sisi positif, pertama pemerintah tahu tuntutan yang diajukan oleh PKL dan yang kedua dengan adanya aksi demonstrasi ini menambah tingkat solidaritas diantara para PKL (Hermawati, Abdoellah, Gunawan, \& Riawanti, 2019). Respon selanjutnya yaitu resistensi tertutup. Resistensi jenis ini dilakukan secara diamdiam, tetapi walaupun secara diam-diam mereka sedang melakukan sebuah perlawanan. Di berbagai artikel disebutkan bahwa PKL di Kendari melakukan resistensi secara diam-diam yaitu bekerjasama dengan tukang ojek untuk memata-matai oknum satpol PP yang akan melakukan razia. Resistensi tertutup juga dilakukan oleh PKL di Salatiga tetapi dengan cara yang berbeda. Mereka berpura-pura mengemasi barang mereka saat Satpol PP sedang melakukan razia, lalu akan kembali berdagang saat satpol PP sudah pergi. Saat satpol PP pergi itulah mereka akan menggerutu dan nggrundel (Husain, Jers, \& Suraya, 2017; Ningsih, 2018). Mereka melakukan hal tersebut untuk menhindari adanya razia yang dilakukan oleh satpol PP atau petugas keamanan yang biasanya akan berujung pada kekerasan.

Selain melakukan resistensi, beberapa PKL memilih untuk tidak melakukan resistensi. Seperti PKL di Surabaya dan PKL di Semarang. Saat terjadi penertiban PKL tersebut memilih untuk diam dan mencari daerah baru untuk berjualan (Parmody, 2018; Handoyo, 2015).

Perbedaan respon tersebut terjadi karena terdapat faktor-faktor yang mendorong seseorang melakukan resistensi dan tidak melakukan resistensi. Berdasarkan data yang diperoleh dari kumpulan artikel yang mengkaji kekerasan pada PKL faktor yang mendorong PKL melakukan resistensi adalah mereka merasa ditindas sehingga butuh adanya perubahan. Seperti yang dikemukakan oleh Scott sebelumnya bahwa resistensi terjadi karena adanya penindasan. Mereka melakukan resistensi untuk mengembalikan hak mereka yang dirampas oleh pihak yang merampas. Kedua, faktor PKL melakukan resistensi adalah modal sosial yang kuat. Sulit untuk melakukan resistensi apabila tidak ada rasa saling memiliki diantara PKL. Sulit mengerahkan para PKL untuk melakukan demontrasi didepan gedung pemerintahan apabila tidak memiliki rasa senasib sepenanggungan. Oleh karena itu modal sosial dianggap penting untuk dimiliki para PKL.

\section{SIMPULAN}

Berdasarkan penelitian yang sudah dilakukan maka dapat disimpulkan mayoritas kekerasan yang disebabkan oleh adanya kebijakan pemerintah terkait dengan penertiban PKL. Konflik tersebut lahir dari adanya perbedaan visi misi PKL dan Pemerintah terkait ruang publik. PKL menafsirkan ruang publik sebagai sarana berjualan mereka, sedangkan pemerintah menganggap bahwa ruang publik merupakan tempat yang harus tertata, rapi serta aman, salah satu misi untuk menciptakan hal tersebut adalah dengan melakukan penertiban PKL. Salah satu cara menertibkan PKL adalah dengan mengeluarkan kebijakan. Tetapi dalam praktek kebijakan tersebut kerap diwarnai dengan aksi kekerasan.

Bentuk kekerasan dibagi menjadi tiga bentuk. Bentuk kekerasan yang pertama 
adalah kekerasan fisik, kekerasan ini meyerang anggota tubuh dan harta serta benda kepunyaan si korban. Bentuk kekerasan fisik diantaranya pemukulan, pengeroyokan, penahanan, pengerusakan barang dagangan, pembakaran lapak dan sebagainya yang dilakukan oleh petugas keamanan terhadap PKL, PKL dengan PKL dan PKL dengan orang diluar kategori tersebut. Selanjutnya bentuk kekerasan PKL adalah kekerasan verbal. Kekerasan verbal adalah kekerasan yang berasal dari mulut berupa ucapan yang mengandung ancaman, hardikan, stigma buruk, labelling dan sebagainya. Terakhir adalah kekerasan struktural. Kekerasan jenis ini tidak dilakukan oleh individu melainkan oleh sekelompok orang yang berada di dalam struktur yang salah. Bentuk kekerasan struktural adalah penyalahgunaan wewenang yang dilakukan petugas keamanan dengan cara melakukan pungutan liar kepada para PKL.

Respon PKL terhadap kekerasan yang dialaminya terbagi menjadi dua yaitu melakukan resistensi dan tidak melakukan resisten. Resistensi menurut James Scott dibagi menjadi dua, resistensi terbuka dan resistensi tertutup. Resitensi terbuka dilakukan secara langsung dan dapat dilihat secara terang-terangan sedangkan resistensi tertutup dilakukan secara sembunyi-sembunyi. Faktor yang mendorong lahirnya resistensi yang dilakukan PKL adalah karena ingin adanya perubahan, selama ini mereka merasa ditindas dengan adanya kebijakan yang dikeluarkan pemerintah, faktor berikutnya yaitu karena adanya modal sosial, rasa senasib sepenanggungan yang mengakibatkan mereka melakukan resistensi.

\section{DAFTAR PUSTAKA}

Adicahya, A. (2017). Penggusuran Pedagang Kaki Lima Sebagai Perbuatan Melanggar Hukum. Justitia Jurnal Hukum, 1(1).

Aisyah, U. (2012). Pedagang Kaki Lima Membandel di Jawa Timur. Jurnal Masyarakat Dan Kebudayaan Politik, 25(1), 47-55
Anjari, W. (2017). Fenomena Kekerasan Sebagai Bentuk Kejahatan (Violence). E-Journal Widya Yustisia, 1(1), 42-51.

Creswell, J. W. (2016). Research Design. Pendekatan Metode Kualitatif, Kuantitatif, dan Campuran. Edisi Keempat. Yogyakarta: Pustaka Pelajar.

Febrianto, T., \& Imron, A. (2014). Resolusi Konflik Pedagang Kaki Lima Di Semolowaru Surabaya. Paradigma, 2(3), 1-9.

Hakim, M., Rosmawati, Zainuddin, R., Halim, H., \& Mana, R. (2015). Pedagang kaki lima dan interrelasi aktor-aktor pariwisata. Asosiasi Prodi Sosiologi Indonesia, 1(1), 494-154.

Handoyo, E. (2015). Makna Ruang Publik Bagi Pedagang Kaki Lima: Studi tentang Resistensi terhadap Penggusuran. Semarang : Seminar Nasional Multi Displin Ilmu \& Call For Papers Unisbank, (hal. 1-12).

Hermawati, R., Abdoellah, O. S., Gunawan, B., \& Riawanti, S. (2019). The Social Movement of Street Vendors to Maintain Their Business Places in Bandung. Masyarakat, Kebudayaan dan Politik, 32(1), 1-15.

Human Right. (2013). Take That Filth Away" Police Abuses Against Street Vendors in Angola. Diambil kembali dari https://www.hrw.org/report/2013/09/29/ take-filth-away/police-abuses-againststreet-vendors-angola

Husain, I. R., Jers, L. O., \& Suraya, R. S. (2017). Resistensi Pedagang Kaki Lima Terhadap Razia Satpol Pp Di Pasar Sentral Kota Lama Kendari. Etnireflika, 6(3), 237-248.

Mirzaqon, T. A., \& Purwoko, B. (2017). Studi Kepustakaan mengenai Landasan Teori dan Praktik Konseling Expressive Writing. Jurnal BK Unesa, 8(1).

Ningsih, A. (2018). Relasi Konflik antara Petugas Keamanan dengan Pedagang Pagi di Kompleks Pasar Raya Kota Salatiga. Ecodinamika, 1-6.

Parmody, R. (2018). Penertiban Satpol PP pada Pedagang Kaki Lima. Jurnal S1 Sosiologi Universitas Airlangga.

Prastya, A. (2018). Perlawanan Pedagang Kaki Lima (Pkl) Terhadap Kebijakan Relokasi Pemerintah Kota Madiun (Studi Kasus: Upaya mempertahankan lapak dalam rangka untuk hidup) (Doctoral dissertation, University of Muhammadiyah Malang).

Ritzer, G., \& Goodman, D. J. (2004). Teori Sosiologi Modern. Jakarta: Prenada Media.

Saha, D. (2011). Working Life Of Street Vendors In Mumbai. The Indian journal of labour economics, 54(2), 301-325.

Santoso, T. (2002). Teori-Teori Kekerasan. (Khadafi, \& J. H. Subijantoro, Penyunt.) Jakarta: Ghalia Indonesia. 
Sarjono, Y. (2005). Pergulatan Pedagang Kaki Lima di Perkotaan. Jakarta: Muhammadiyah University Press.

Scott, J. C. (2000). Senjatanya Orang-Orang yang Kalah. Jakarta: Yayasan Obor Indonesia.

Soehadha. (2014). Kekerasan Kolektif Dan Dialog Kebudayaan: Belajar Dari Pengalaman Kekerasan Menjelang Reformasi di Indonesia. ESENSIA: Jurnal Ilmu-Ilmu Ushuluddin.
Sundalangi, F. (2009). Penanggulangan Masalah Pedagang Kaki Lima di Kota Manado Pada Perspektif PKL. JBE (Journal of Business and Economics), 95-102.

WIEGO. (2018). Violence and Informal Work. WIEGO: Women in Informal Employment; Globalizing and organizing. 